\title{
Tumor fibroso solitario de la cavidad oral : Reporte de dos casos.
}

\section{Andréia Aparecida da Silva ${ }^{1}$ Jorge Esquiche León ${ }^{2}$ Danyel Elias da Cruz Perez ${ }^{3}$ Oslei Paes de Almeida ${ }^{4}$ Márcio Ajudarte Lopes ${ }^{4}$ Pablo Agustin Vargas ${ }^{4}$}

${ }^{1}$ Alumno del Curso de Maestría en Estomatopatología, Universidad Estadual de Campinas/ Facultad del Odontología de Piracicaba. Universidad Estadual de Campinas, UNICAMP, São Paulo, Brasil.

Alumno del Curso de Doctorado en

Estomatopatología, Universidad Estadual de

Campinas/ Facultad del Odontología de Piracicaba. Universidad Estadual de Campinas, UNICAMP, São Paulo, Brasil.

${ }^{3}$ Docente del Departamento de Patología Oral. Universidad de Ribeirão Preto, UNAERP, São Paulo, Brasil.

${ }^{4}$ Docente del Departamento de Patología Oral. Universidad Estadual de Campinas/ Facultad del Odontología de Piracicaba. Universidad Estadual de Campinas, UNICAMP, São Paulo, Brasil. da Silva AA, Esquiche J, Perez DE, de Almeida OP, Lopes MA, Vargas PA. Tumor fibroso solitario de la cavidad oral : Reporte de dos casos. Rev Estomatol Herediana 2005; 15 (2) $161-167$.

\section{RESUMEN}

El tumor fibroso solitario (TFS) es una neoplasia benigna de células fusiformes que ha sido principalmente descrito en la pleura visceral y en cavidades serosas, no común en la región de cabeza y cuello, con pocos casos intraorales reportados en la literatura. Describimos aquí dos casos adicionales afectando la cavidad oral, los cuales estuvieron localizados en el carrillo izquierdo. El examen histológico mostró lesiones fusocelulares bien circunscritas en padrón estoriforme y hemangiopericítico exhibiendo alternancia de áreas hipercelulares con hipocelulares. Los hallazgos inmunohistoquímicos fueron similares en ambos casos revelando fuerte inmunorreactividad para vimentina, CD34, bcl-2 y negatividad para actina músculo específico, actina músculo liso, S100 y citoqueratinas de amplio espectro. Basado en las características clínicas, microscópicas e inmunohistoquímicas, el diagnóstico final de estos dos casos fue de TFS oral benigno. Así, el TFS deberá ser incluido en el diagnóstico diferencial de lesiones nodulares envolviendo la mucosa bucal. Los clínicos y patólogos orales deberán ser capaces de reconocer este importante tumor de células fusiformes orales.

Palabras clave: Tumor fibroso solitario, Inmunohistoquímica, Cavidad oral.
Andréia Aparecida da Silva

Avenida Limeira, 901, Areião

Piracicaba, SP, Brasil

CEP: $13414-903$

Teléfono: +55-19-3412-5315

e-mail: andreia@fop.unicamp.br

\section{Introducción}

El tumor fibroso solitario (TFS) es una inusual neoplasia de células fusiformes que típicamente involucra la pleura visceral siendo originalmente conocido como fibroma pleural o mesotelioma fibroso (1). Fue primeramente descrito por Klemperer y Rabin en 1931, como una neoplasia de la pleura benigna o maligna. Posteriormente fue descrito en varios sitios extrapleurales como los pulmones, mediastino, peritoneo, médula espinal, tejidos blandos, tracto sinonasal, nasofaringe, tiroides, cavidad orbitaria, periostio, hígado, cápsula renal, piel, cavidad oral y glándulas salivales (2-8). En la literatura inglesa, encontramos relatados solamente 36 casos de TFS oral benigno (4, 8-12). Clíni- camente se presenta como un nódulo submucoso de variable tamaño, móvil, asintomático, bien circunscrito y cubierto por mucosa normal (9). En coloraciones de H\&E, el TFS puede ser difícil de ser distinguido de otros tumores de células fusiformes orales, ya que clásicamente son considerados por mostrar un padrón polimórfico ("padrón sin padrón"). La inmunohistoquímica es de valiosa ayuda para confirmar el diagnóstico, siendo positivos para vimentina, CD34, CD99 y bcl-2 (13).

En este reporte, describimos dos casos adicionales de TFS intraoral benigno, enfatizando el diagnóstico diferencial así como también sus características histopatológicas e inmunohistoquímicas.

\section{Reporte de caso Caso 1}

Un paciente masculino de 38 años de edad, caucásico, fue referido al servicio de Diagnóstico Oral (Orocentro) de la Facultad de Odontología de Piracicaba - UNICAMP, Brasil, quejándose de una lesión oral con 1 mes de evolución, la cual permanecía estable después de su detección. El paciente tenía aparente buen estado de salud, siendo la historia médica general no contribuyente. El examen intraoral mostró una lesión nodular submucosa móvil, bien delimitada, asintomática, de consistencia fibroelástica midiendo 2,0 x 2,0 cm, localizado en la mucosa yugal izquierda y cubierta por mucosa de apariencia normal. Nuestro diagnóstico clí- 
nico fue de tumor mesenquimal benigno (Fig. 1). Se procedió a efectuar una biopsia excisional bajo anestesia local y el espécimen fue sometido a análisis histopatológico. Microscópicamente, el tumor fue bien circunscrito, exhibiendo áreas hipercelulares sin padrón definido o áreas estoriformes de células fusiformes alternando con áreas hipocelulares (Fig. 2). En las áreas hipocelulares, las células tumorales estuvieron embebidas en una matriz colagenosa densa hialinizada (Fig. 3). Áreas con apariencia hemangiopericítica estuvieron dispersas en el estroma tumoral. El número de figuras mitóticas fue $<2 / 10$ campos de gran aumento. No fueron observadas necrosis, atipia nuclear, hemorragia y pleomorfismo.

\section{Caso 2}

Un paciente masculino de 55 años de edad, caucásico, fue referido a la Clínica de Odontología de la Universidad de Ribeirão Preto (UNAERP), Brasil, quejándose de un nódulo en la mucosa yugal izquierda con 3 años de evolución. La historia médica así como el examen extrabucal fue no contribuyente. El examen intraoral mostró un nódulo submucoso móvil, fibroelástico, bien circunscrito, asintomático, localizado en la mucosa yugal izquierda. La lesión medía $3.5 \times 2.5 \mathrm{~cm}$, siendo recubierta por mucosa normal. Con la principal hipótesis clínica de un tumor mesenquimal benigno, la lesión fue fácilmente removida bajo anestesia local. Microscópicamente, la lesión era formada por áreas hipercelulares e hipocelulares, sin un padrón específico. Las áreas hipercelulares eran compuestas por células fusiformes mixturadas con numerosos vasos sanguíneos en padrón hemangiopericítico. Las áreas hipocelulares presentaban predominantemente fascículos de fibras colágenas dispuestos en diferentes direcciones. No se observaron atipias celulares, mitosis atípicas o necrosis.

\section{Hallazgos inmunohistoquímicos}

A partir del material de la biopsia fijada en formol tamponado y embebida en parafina, fueron obtenidos cortes de $3 \mu \mathrm{m}$ de espesor, las cuales fueron desparafinizadas, hidratadas e inactivadas con peróxido de hidrógeno al 3\% para inhibir la peroxidasa endógena. Para la recuperación de antígenos, los especímenes fueron tratados con tampón citrato pH 6 en horno de micro-ondas, seguido por incubación con el anticuerpo primario durante 16 horas (Tabla 1 ), usando apropiados controles positivos y negativos. Para la detección de los anticuerpos primarios, usamos anticuerpos secundarios conjugados con estreptavidina-biotina-peroxidasa (Strept ABComplex/HRP Duet, Mouse/Rabbit, Dako A/S, Denmark), las cuales fueron revelados usando el cromógeno diaminobenzidina y contracoloreados con hematoxilina de Carazzi. La expresión de los inmunomarcadores fueron considerados como siendo positivos o negativos. Las células tumorales mostraron fuerte inmunoreactividad para vimentina, CD34 (Fig. 4) y bcl-2 (Fig. 5) en ambos casos y fueron negativos fueron obtenidos con actina músculo específico, actina músculo liso, S100 y citoqueratinas de amplio espectro (AE1/AE3). Estos hallazgos confirmaron el diagnóstico de TFS.
Ninguna recurrencia fue detectada durante 1 y 10 años de seguimiento en el primer y segundo caso, respectivamente.

\section{Discusión}

Aunque la ocurrencia del TFS estuvo pensada ser confinada a la cavidad serosa pleural, existen numerosos reportes de esta lesión en localizaciones extrapleurales, particularmente afectando extremidades, tronco y retroperitoneo. Es interesante el hecho de que estos tumores alcanzaran tamaños considerables $(>10 \mathrm{~cm})$. No parece haber predilección por el sexo y ocurre primariamente en adultos, siendo rara su presentación en adolescentes (14). El promedio de edad de los pacientes con TFS oral es de 59 años (9). Aunque claramente el TFS es de origen mesenquimal, su histogénesis es desconocida, siendo las principales candidatas las células mesenquimales primitivas dendríti$\operatorname{cas}(9,15,16)$.

Microscópicamente, todos los TFS exhiben similar morfología a despecho de su localización anatómica. Son caracterizados por mostrar áreas hipercelulares e hipocelulares, una matriz colagenosa esclerótica y vasos sanguíneos en padrón hemangiopericítico. Aunque las células están distribuidas al azar, ellas pueden mostrar un padrón estoriforme $(2,11,17)$. El tumor usualmente exhibe inmunoreactividad para vimentina, CD34, bcl-2, CD99 y factor XIIIa, pero es negativo para actina músculo específico, actina músculo liso, S100 y citoqueratinas $(2,8,12,15,17-19)$. Similar a CD34, CD99 es un marcador consistente-mente encontrado en el TFS,

Tabla 1. Inmunomarcadores usados en el diagnóstico de los tumores fusocelulares.

\begin{tabular}{lllc}
\hline Anticuerpos / clones & Fuente & Dilución & Recuperación antigénica \\
Vimentina/V9 & Dako & $1 / 200$ & Microondas \\
CD34/QBEnd 10 & Dako & $1 / 50$ & Microondas \\
Bcl-2/ 124 & Dako & $1 / 50$ & Microondas \\
Citoqueratinas/ AE1/AE3 & Dako & $1 / 200$ & Microondas \\
S-100* & Dako & $1 / 1000$ & Microondas \\
Actina alfa músculo liso / 1A4 & Dako & $1 / 200$ & Microondas \\
Actina músculo específico / HHF35 & Dako & $1 / 200$ & Microondas \\
\hline
\end{tabular}

* Policlonal 


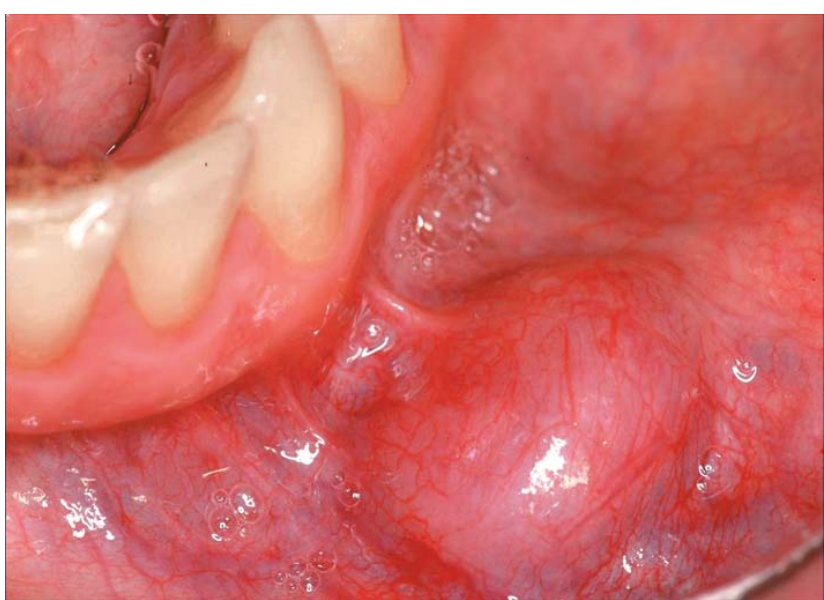

Fig. 1. Lesión nodular en la mucosa bucal cubierto por mucosa de apariencia normal.

Nodular lesion in the buccal mucosa covered by mucosa of normal appearance.

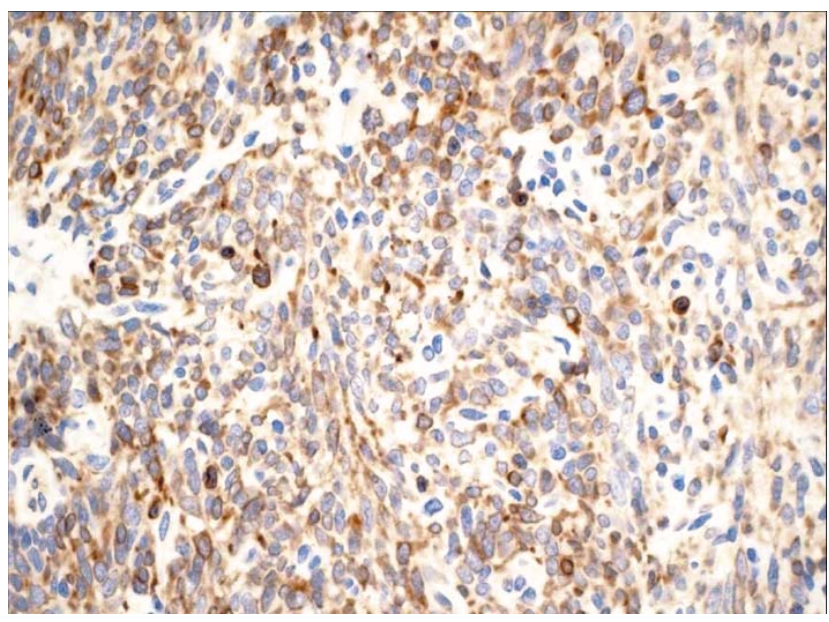

Fig. 3. Área hipocelular mostrando células fusiformes y linfocitos inmersas en una matriz colagenosa densa hialinizada (H\&E, x200). Hypocellular area showing spindle cells and lymphocytes immersed in a hyalinized dense colagenous matrix (H\&E, x200).

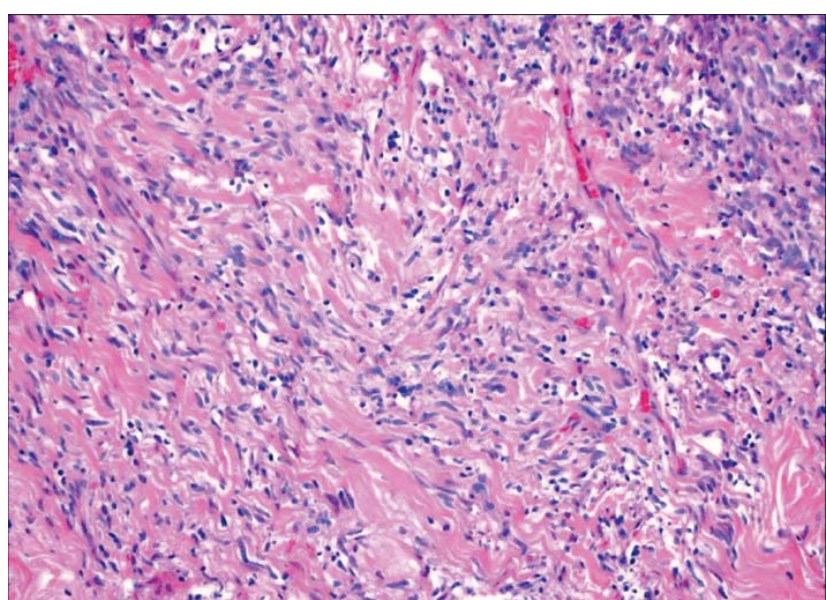

Fig. 2. Área hipercelular de células fusiformes exhibiendo superficie bien delimitada (H\&E, x 200).

Hypercellular spindle cells areas exhibiting well-circumscribed surface $(H \& E, x 200)$.

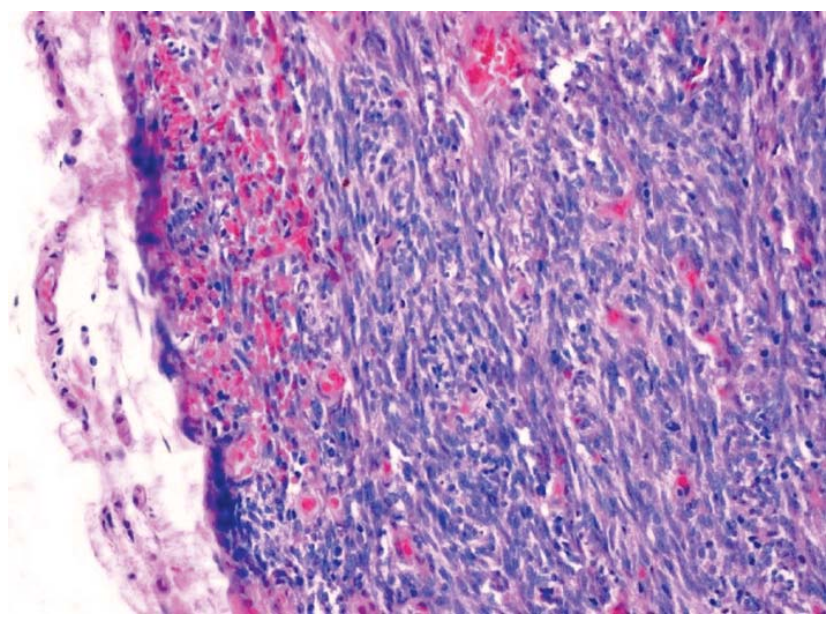

Fig. 4. Células tumorales con fuerte expresión de CD34 en patrón de membrana (Inmunohistoquímica, x200).

Strong CD34 expression in tumor cells in membranous pattern (Immunohistochemistry, original magnification x200).

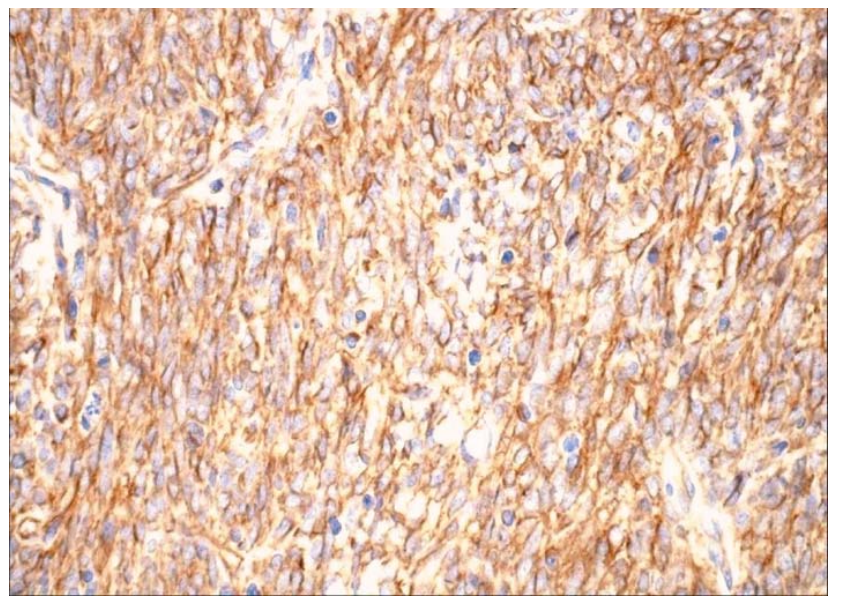

Fig. 5. Inmunoreactividad citoplasmática positiva en las células tumorales para bcl-2 (Inmunohistoquímica, x200). Positive cytoplasmic immunoreactivity for bcl-2 in tumor cells (Immunohistochemistry, original magnification x200). 
en cuanto EMA (antígeno epitelial de membrana) y desmina pueden ser positivos en casos esporádicos (13).

La molécula CD34 es una glicoproteína transmembrana de cadena única relacionada a subgrupos de células progenitoras hematopoyéticas mieloides $(8,20)$. Según Regezi et al. (1992) (16), los dendrocitos submucosos orales exhiben positividad para CD34 y el factor XIIIa. Aunque CD34 es comúnmente positivo en el TFS, es también expresado en otras entidades, tales como leucemia, neoplasmas vasculares, neoplasmas derivados de músculo liso, tumores de la vaina nerviosa y dermatofibrosarcoma protuberans $(2,11)$. La proteína bcl-2 está localizada en la membrana mitocondrial y está relacionada a un aumento de sobrevida celular inhibiendo la apoptosis. Nuestros casos fueron fuertemente positivos para vimentina, CD34 y bcl-2, confirmando la naturaleza mesenquimal del tumor, su probable origen a partir de células dendríticas intersticiales así como también la posible inhibición de la apoptosis. Este tumor es usualmente bien delimitado y aparentemente encapsulado. Sin embargo, la presencia de un número incrementado de figuras mitóticas ( $>4 / 10$ campos de grande aumento), pleomorfismo nuclear, hipercelularidad, hemorragia y necrosis pueden indicar la presencia de una variante maligna la cual generalmente está asociada con un curso clínico agresivo (13,21). Estas características histopatológicas estuvieron ausentes en nuestros casos, confirmando su curso benigno. Sin embargo, concordamos con Vallat-DeCouvelaere et al. (1998) (13) sobre el seguimiento que deben re- cibir estos pacientes. La mayoría de los casos extrapleurales publicados muestran un curso benigno, pero esto probablemente refleja el relativo corto tiempo de seguimiento y al igual que las lesiones pleurales, es posible que algunos casos puedan recurrir o causar metástasis (13).

El diagnóstico diferencial del TFS incluye : fascitis nodular (FN), histiocitoma fibroso (HF), schwannoma, leiomiosarcoma, fibrosarcoma, miofibroma, tumor desmoide, dermatofibrosarcoma protuberans y neurofibrosarcoma $(2,11)$. Tanto la FN y el TFS son compuestos de células fusiformes y fibras de colágeno, sin embargo el TFS presenta un padrón estromal no definido cuando es comparado al estroma fibrilar observado en la FN. Además, inmunohistoquímicamente la FN es positiva para actina músculo liso y el TFS es positivo para CD34 (22). El HF y el TFS pueden mostrar áreas estoriformes similares, siendo este padrón más prevalente en el primero. Por otro lado, el TFS exhibe más áreas escleróticas que el HF (6). El Schwannoma es un tumor encapsulado compuesto de células de Schwann cuyos núcleos tienden a mostrar palizadas, formando los cuerpos de Verocay distintivos de áreas Antoni A; encuanto las áreas paucicelulares y mixoides muestran hialinización perivascular característicos de áreas Antoni B. La expresión positiva para S100 es típicamente sugestiva de la naturaleza neural de estos tumores $(18,23)$. El leiomiosarcoma y fibrosarcoma pueden raramente envolver tejidos blandos orales, pero ellos pueden ser distinguidos del TFS por sus características citoló- gicas malignas, padrón infiltrativo, falta de expresión de CD34 e inmunoreactividad positiva para actina y miosina en el caso del tumor muscular (19). El tumor maligno de la baina del nervio periférico es otra neoplasia maligna incomún de células fusiformes en la cavidad oral que comparte algunas características morfológicas y expresión de CD34 con el TFS. Sin embargo, a diferencia del TFS, este tumor maligno muestra moderada a fuerte inmunorreactividad para S100 (19). El miofibroma solitario también es no común en la cavidad oral que puede ser distinguido del TFS, considerando la celularidad y morfología nuclear. Este tumor expresa actina músculo liso, el cual es usualmente ausente en el TFS y es negativo para CD34 (19). El tumor desmoide tiene una presentación rara en la cavidad oral, pero al igual que el tumor anterior falta en la expresión de CD34 y exhibe un aspecto histopatológico monótono (24). El dermatofibrosarcoma protuberans es un tumor maligno de bajo grado, que ha sido reportado en la cavidad oral. Aunque estos tumores son frecuentemente CD34 positivos, son generalmente bcl-2 negativos (12).

En resumen, en el presente artículo relatamos los aspectos clínicos, microscópicos e inmunohistoquímicos de dos casos adicionales de TFS oral. Esta neoplasia es poco común en la cavidad oral, pero deberá ser considerada en el diagnóstico diferencial de lesiones nodulares de la mucosa formada por células fusiformes. Enfatizamos el diagnóstico microscópico diferencial, incluyendo el uso de los inmunomarcadores, así como también recomendar un cuidadoso seguimiento en estos pacientes. 


\section{Solitary fibrous tumor of the oral cavity : a report of two cases and review of the literature.}

da Silva AA, Esquiche J, Perez DE, de Almeida OP, Lopes MA, Vargas PA. Solitary fibrous tumor of the oral cavity : a report of two cases and review of the literature. Rev Estomatol Herediana 2005; 15 (2) : 161 - 164.

\section{ABSTRACT}

Solitary fibrous tumor (STF) is a benign spindle-cell neoplasm that has been described mainly in the visceral pleura and other serosal sites, which is uncommon in the head and neck region, with few oral cases reported in the literature. We describe two additional cases of SFT affecting the mouth, which were located in the left cheek. Histological examination showed well-circumscribed spindled cell lesion with storiform and hemangiopericytic patterns, exhibiting alternating hypercellular and hypocellular areas. The immunohistochemical findings were similar in both cases, with strong immunoreactivity for vimentin, CD34, bcl-2 and negative for muscle specific actin, smooth muscle actin, S-100 protein and pancytokeratin. Based on these clinical, microscopical and immunohistochemical features the final diagnosis of these two cases was benign oral SFT. Therefore SFT should be included in the differential diagnosis of nodular lesions involving the buccal mucosa. The clinicians and oral pathologists should be able to recognize this important oral spindle cell tumor.

Keywords: Fibrous solitary tumor, Immunohistochemistry, Oral cavity.

\section{Introduction}

Solitary fibrous tumor (SFT) is an unusual spindle-cell neoplasia that typically involves the visceral pleura, that originally was denominated pleural fibroma or fibrous mesotelioma (1). SFT was described by Klemperer \& Rabin in 1931, as a benign or malignant neoplasia of the pleura. Afterwards it was described in many extrapleural sites such as the lungs, mediastinum, peritoneum, spinal cord, soft tissues, sinonasal tract, nasopharynx, thyroid, orbit, periosteum, liver, renal capsule, skin, oral cavity and salivary glands (28 ). We found only 36 benign oral SFT reported in the English literature (4, 812). Clinically, it presents as a movable, asymptomatic, well-circumscribed submucous nodule of variable size, covered by normal mucosa (9). In H\&E preparations, SFT can be difficult to be distinguished from other oral spindle cells tumors, although classically it is considered to show a polimorphic pattern ("pattern without pattern"). Immunohistochemistry is helpful to confirm the diagnosis, and it is positive for vimentin, CD34, CD99 and bcl-2 (13).

In this report, we describe two additional cases of benign oral SFT emphasizing the differential diagnosis as well as it's histopathological and immunohistochemical features.

\section{Case report \\ Case 1}

A 38 year-old Caucasian man was referred to the Oral Diagnosis Clinic (OROCENTRO) at the School of Dentistry of Piracicaba - UNICAMP, Brazil, complaining of an oral lesion with 1 month of evolution, which remained unaltered after its detection. The patient was otherwise healthy, and the general medical history was noncontributory. Intraoral examination showed a mobile, well-delimited, painless, submucous nodular lesion of fibroelastic consistency measuring $2.0 \times 2.0 \mathrm{~cm}$, located in the left buccal mucosa and covered by normal mucosa. Our clinical diagnosis was benign mesenchymal tumor (Fig. 1). Under local anesthesia, it was carried out an excisional biopsy and the speci-men was submitted to histopathologic analysis. Microscopically the tumor was wellcircumscribed, exhibiting hypercellular areas without defined pattern or storiform regions of spindle cells alternating with hypocellular areas (Fig. 2). In the hypocellular areas, tumor cells were immersed in a hyalinized dense colagenous matrix (Figs. 3). Areas with hemangiopericytoma-like pattern were dispersed in the tumoral stroma. Number of mitotic figures was $<2 / 10$ high power field. Necrosis, nuclear atypia, hemorrhage and pleomorphism were not observed.

\section{Case 2}

A 55 year-old Caucasian man was referred to the Odontologic Clinic of the University of Ribeirão Preto (UNAERP), Brazil, complaining of a nodule in the left buccal mucosa with 3 years of evolution. Medical history and extrabuccal evaluation were noncontributory. Intraoral examination showed a fibroelastic, well-circumscribed, painless, movable submucous nodule in the left buccal mucosa. The $3.5 \times 2.5 \mathrm{~cm}$ lesion was covered by normal mucosa. With the main clinical hypothesis of benign mesenquimal tumor, the lesion was easily removed under local anesthesia. Microscopically the lesion was formed by hyper and hypocellular areas without a specific pattern. The hypercellular areas were composed by spindle cells mixed with numerous blood vessels presenting a hemangiopericytoma-like pattern. The hypocellular areas were formed predominantly by fascicles of collagenous fibers distributed in various directions. No cellular atypia, atypical mitosis or necrosis were observed.

\section{Inmunohistochemical findings}

From the formalin-fixed and paraffinembedded tissue were obtained $3 \mu \mathrm{m}$ sections, which were deparaffinized, hydrated and treated with 3\% hydrogen peroxide to inhibit endogenous peroxi- 
dase. For antigen retrieval, the specimens were treated with citrate buffer $\mathrm{pH} 6$ in microwave, followed by incubation with the primary antibody for 16 hours (Table 1), using appropriate positive and negative controls. For the detection of the primary antibodies, we used secondary antibodies conjugated with streptavidin-biotin-peroxidase (Strept ABComplex/HRP Duet, Mouse/Rabbit, Dako A/S, Denmark), which were revealed by diaminobenzidine chromogen and counterstained with Carazzi's hematoxylin. The expression of the immunomarkers was considered as positive or negative. Tumors cell showed strong immunoreactivity for vimentin, CD34 (Fig. 4) and bcl-2 (Fig. 5) in both cases and were negative for muscle-specific actin, smooth muscle actin, S100 protein and pan-cytokeratin (AE1/AE3). These findings confirmed the diagnosis of SFT.

No recurrence was detected after 1 and 10 years of follow-up of cases 1 and 2 , respectively.

\section{Discussion}

SFT was initially thought to be confined to the pleura, but there are numerous reports of SFT in extrapleural sites, particularly affecting extremities, trunk and retroperitoneum. It is interesting it can reach a huge size $(>10 \mathrm{~cm})$. SFT does not present predilection for gender and primarily occur in adults, being rare in adolescents (14). The mean age of the patients with oral SFT is 59 years old (9). Although SFT clearly is of mesenchymal origin, the histogenesis is unknown, but dendritic primitive mesenchymal cells, are the main candidates $(9,15,16)$.

Microscopically, all SFT exhibit similar morphology despite of the anato- mical location. It is characterized by hypercellular and hypocellular areas, sclerotic collagenic matrix and blood vessels forming a hemangiopericytomalike pattern. Although the cells are distributed haphazardly, sometimes they can show a storiform pattern $(2,11,17)$. The tumor usually exhibits immunoreactivity for vimentin, CD34, bcl-2, CD99, and factor XIIIa, but it is negative for specific muscle actin, smooth muscle actin, S100 protein and cytokeratins (2, $8,12,15,17-19)$. Like CD34, CD99 is a marker consistently found in SFT, whereas EMA (epithelial membrane antigen) and desmin can be positive in sporadic cases (13).

CD34 is a single-chain transmembrane glycoprotein related to subsets of myeloid haematopoietic progenitor cells $(8,20)$. According to Regezi et al. (1992) (16), the oral submucous dendrocytes exhibit positivity for CD34 and factor XIIIa. Although CD34 is commonly positive in SFT, it is also expressed in other entities, such as leukemia, vascular neoplasms, derivedsmooth muscle tumors, tumors of the nervous sheath and dermatofibrosarcoma protuberans $(2,11)$. Bcl-2 protein is located in the mitochondrial membrane and it is related to an increased of the cellular survival as it inhibits apoptosis. Our cases were strongly positive for vimentin, CD34 and bcl-2, confirming the mesenchymal nature of the tumor, its probable interstitial dendritic cell origin, as well as the possible apoptosis inhibition. This tumor usually is welldelimited and apparently encapsulated. However, the presence of an increased number of mitotic figures $(>4 / 10$ high power field), nuclear pleomorfism, hypercelullarity, hemorrhage and necrosis can indicate a possible malignant variant, which generally is associate with aggressive clinical course (13, 21). These histopathologic characteristics were absent in our cases, confirming its benign nature. Nevertheless, we agree with Vallat-DeCouvelaere et al. (1998) (13) about the follow-up that these patients must receive. Most of the extrapleural cases published showed a benign course, but most were followed up for a relatively short time, and as in the pleural lesions it is possible that some cases may recur or cause metastasis (13).

The differential diagnosis of SFT includes nodular fasciitis (NF), fibrous histiocytoma (FH), schwannoma, leiomiosarcoma, fibrosarcoma, myofibroma, desmoid tumor, dermatofibrosarcoma protuberans and neurofibrosarcoma (2, 11). Both NF and SFT are composed of spindle cells and collagen fibers, but SFT presents no defined stromal pattern when compared to the fibrilar stroma observed in NF. In addition, immunohistochemically NF is positive for smooth muscle actin and SFT for CD34 (22). FH and SFT can show similar storiform areas, but this pattern is more frequent in NF. On the other hand, SFT exhibits more sclerotic areas than FH(6). Schwannoma is an encapsulated tumor composed by Schwann's cells with nuclei that tend to show palisading, forming Verocay bodies, features of Antoni A areas; while the paucicelular and myxoid areas show perivascular hyalinization, features of Antoni B regions. The positive expression for S100 protein is typically suggestive of the neural nature of these tumors (18, 23). Leiomyosarcoma and fibrosarcoma may rarely involve the oral soft tissues, but they can be distinguished from SFT

Table 1. Immunomarkers used in the diagnosis of spindle cell tumors.

\begin{tabular}{llll}
\hline Antibodies / clones & Source & Dilution & Antigen retrieval \\
Vimentin/V9 & Dako & $1 / 200$ & Microwave \\
CD34/QBEnd 10 & Dako & $1 / 50$ & Microwave \\
Bcl-2/ 124 & Dako & $1 / 50$ & Microwave \\
Cytokeratins/ AE1/AE3 & Dako & $1 / 200$ & Microwave \\
S-100* & Dako & $1 / 1000$ & Microwave \\
Alfa-smooth muscle actin/1A4 & Dako & $1 / 200$ & Microwave \\
Muscle actin specific/ HHF35 & Dako & $1 / 200$ & Microwave \\
\hline
\end{tabular}

* Polyclonal 
by their malignant cytological features, infiltrative pattern, lack of CD34 expression and positive immunoreactivity for actin and myosin in the case of the muscular tumor (19). The malignant peripheral nerve sheath tumor is other neoplasm formed by spindle cells uncommon in the oral cavity, which shares morphologic characteristics and expression of CD34 with SFT. Nevertheless unlike to SFT this malignant tumor shows moderate to strong inmunoreactivity for S100 protein (19). Solitary myofibroma also is uncommon in the oral cavity, and it can be distinguished from SFT, considering the cellularity and nuclear morphology. This tumor expresses smooth muscle actin, which is usually absent in SFT, and it is negative for CD34 (19). Desmoid tumor is rare in the oral cavity, exhibiting monotonous histopathologic aspect and lack expression of CD34 (24). Dermatofibrosarcoma protuberans is a low grade malignant tumor that has been reported in the oral cavity. Although it is frequently positive for CD34, it is negative for bcl-2 (12).

In summary, in the present article we reported the clinical, microscopic and immunohistochemical findings of two additional cases of oral SFT. It is uncommon in the oral cavity, but it should be considered in the differential diagnosis of nodular lesions of the mucosa formed by spindle cells. We emphasized the microscopical differential diagnosis, including the use of immunomarkers, as well as recommending a careful followup of these patients.

\section{References}

1. England DM, Hochholzer L, McCarthy MJ. Localized benign and malignant fibrous tumors of the pleura. A clinicopathologic review of 223 cases. Am J Surg Pathol 1989; 13(8): 640-58.

2. Gerhard R, Fregnani ER, Falzoni R, Siqueira SAC, Vargas PA. Cytologic features of fibrous tumor of the parotid gland. A case report. Acta Cytol 2004; 48(3): 402-6.

3. Klemperer P, Rabin CB. Primary neoplasms of the pleura: A report of five cases. Arch Pathol 1931; 11: 385-411

4. Harada T, Matsuda H, Maruyama R, Yoshimura Y. Solitary fibrous tumours of the lower gingiva: a case report. Int J Oral Maxillofac Surg 2002; 31(4): 448-50.

5. Pizzolitto S, Falconieri G, Demaglio G. Solitary fibrous tumor of the spinal cord: a clinicopathologic study of two cases. Ann Diagn Pathol 2004; 8(5): 268-275.

6. Kurihara K, Mizuseki K, Sonobe J, Yanagihara J. Solitary fibrous tumor of the oral cavity: report of a case. Oral Surg Oral Med Oral Pathol Oral Radiol Endod 1999; 87(2): 223-6.

7. Tihan T, Viglione M, Rosenblum MK, Olivi A, Burger PC. Solitary fibrous tumors in the central nervous system. A clinicopathologic review of $18 \mathrm{ca}$ ses and comparison to meningeal hemangiopericytomas. Arch Pathol Lab Med 2003; 127(4): 432-9.

8. Lukinmaa PL, Hietanen J, Warfvinge G, Sane J, Tuominen S, Henrikesson V, Larsson A. Solitary fibrous tumor of the oral cavity: clinicopathological and immunohistochemical characterization of three cases. J Oral Pathol Med 2000; 29(4): 186-92.

9. Veltrini VC, Etges A, Magalhaes MH, de Araujo NS, de Araujo VC. Solitary fibrous tumor of the mucosa-morphological and immunohistochemical profile in the differential diagnosis with hemangiopericytoma. Oral Oncology 2003; 39(4): 420-6.

10. Ide F, Saito I. Oral solitary fibrous tumour. Oral Dis 2002; 8(6): 314-5.

11. Vargas PA, Alves FA, Lopes MA, Siqueira SA, Menezes LF, Aldred VL, Almeia OP. Solitary fibrous tumour of the mouth: report of two cases involving the tongue and cheek. Oral Dis 2002; 8(2): 111-5.

12. Alawi F, Stratton D, Freedman PD. Solitary fibrous tumor of the oral soft tissues: a clinicopathologic and immunohistochemical study of 16 cases. Am J Surg Pathol 2001; 25(7): 900-10.

13. Vallat-DeCouvelaere AV, Dry SM, Fletcher CD. Atypical and malignant solitary fibrous tumors in extrathoracic locations: evidence of their comparability to intra-thoracic tumors. Am J Surg Pathol 1998; 22(12): 1501-11.

14. Yamashita Y, Satoh T, Goto M. Solitary fibrous tumor of the tongue: a case report with immunohistochemical studies. Int J Oral Maxillofac
Surg 2002;31(6): 681-3.

15. Shimoyama T, Horie N, Ide F. Solitary fibrous tumor of the palate: a case report and review of the literature. J Oral Maxillofac Surg 2004; 62(7): 8957.

16. Regezi JA, Nickoloff BJ, Headington JT. Oral submucosal dendrocytes; factor XIIIa+ and CD34+ dendritic cell population in normal tissue and fibrovascular lesions. J Cutan Pathol 1992; 19(5): 398-406.

17. Iwai S, Nakazawa M, Yoshikawa F, Amekawa S, Sakuda M. Solitary fibrous tumor of the buccal mucosa: report of a case with immunohistochemical studies. Oral Surg Oral Med Oral Pathol Oral Radiol Endod 1999; 88(4): 461-5.

18. Jordan RC, Regezi JA. Oral spindle cell neoplasms: a review of 307 cases. Oral Surg Oral Med Oral Pathol Oral Radiol Endod 2003; 95(6): 717-24.

19. Perez-Ordonez B, Koutlas JG, Strich E, Gilbert RW, Jordan RC. Solitary fibrous tumor of the oral cavity: an uncommon location for a ubiquitous neoplasm. Oral Surg Oral Med Oral Pathol Oral Radiol Endod 1999; 87(5): 589-93.

20. Shin JH, Sung IY, Suh JH, Yang SO, Jeong YK, Lee JH, Hwang JC. Solitary fibrous tumor in the buccal space: MR finding with pathologic correlation. AJNR Am J Neuroradiol 2001;22(10): 1890-2.

21. Shnayder Y, Greenfield BJ, Oweity T, DeLacure MD. Malignant solitary fibrous tumor of the tongue. Am J Otolaryngol 2003; 24 (4): 246-9.

22. Eversole LR, Christensen R, Ficarra G, Pierleoni L, Sapp JP. Nodular fasciitis and solitary fibrous tumor of the oral region: tumors of fibroblast heterogeneity. Oral Surg Oral Med Oral Pathol Oral Radiol Endod 1999; 87(4): 461-6.

23. Wu SL, Vang R, Clubb FJ Jr, Connelly JH. Solitary fibrous tumor of the tongue: report of a case with immunohistochemical and ultrastructural studies. Ann Diagn Pathol 2002; 6(3): 168-71.

24. Fowler CB, Hartman KS, Brannon RB. Fibromatosis of the oral and paraoral region. Oral Surg Oral Med Oral Pathol Oral Radiol Endod 1994; 77(4):377-86. 